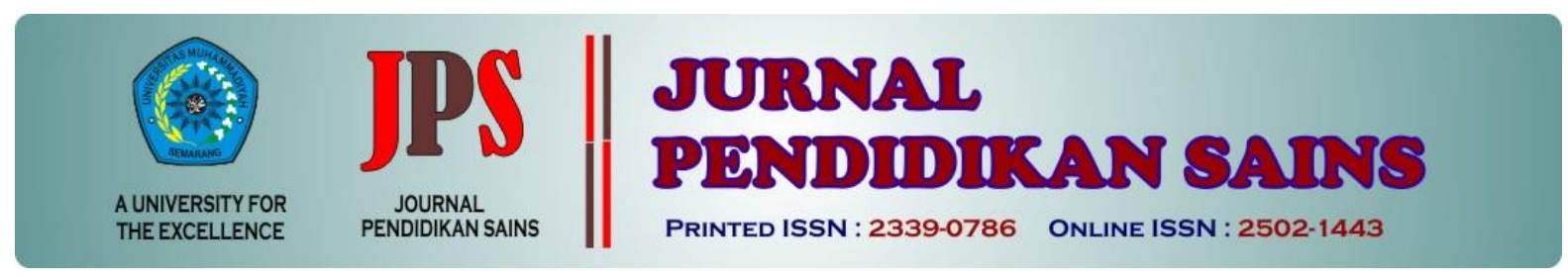

http://jurnal.unimus.ac.id/index.php/JPKIMIA

\title{
PENGARUH PENGGUNAAN HANDOUT TERHADAP HASIL BELAJAR FISIKA SISWA KELAS VIII SMP N 3 TUMIJAJAR
}

\author{
Oleh: \\ Erni Mariana ${ }^{1}$, Ayang Kinasih ${ }^{2}$ \\ Universitas Nahdlatul Ulama Lampung \\ email: ernimariana@unulampung.ac.id ${ }^{1}$
}

\begin{tabular}{|c|c|}
\hline Article history & Abstract \\
\hline : 2020-08-20 & \multirow{5}{*}{$\begin{array}{l}\text { The selection of learning media must be considered several things, } \\
\text { including the ease and use, handouts are learning media that are easy } \\
\text { to make and use. This study aims to determine the effect of using } \\
\text { handouts on the physics learning outcomes of grade VIII students of } \\
\text { SMP Negeri } 3 \text { Tumijajar even semester. The research design used was } \\
\text { Posttest-Only Control Design and the research instruments were } \\
\text { observation sheets, questionnaire sheets and tests. The data analysi } \\
\text { technique used is the calculation of the normality test, the } \\
\text { homogeneity test, the two mean similarity test, and the two mean } \\
\text { difference test. Research shows that the value }{ }_{t} \text { of } 3.49 \text { was greater } \\
\text { than }{ }^{-} \text {table at } 2.00 \text { at significance level } \alpha=5 \% \text {, as well as the } \\
\text { significance level } \alpha=1 \% \mathrm{t} \text { is greater than } \mathrm{t}_{\text {-table by } 2.66 \text {. So the }} \text { by } \\
\text { hypothesis which states that there is an effect of the use of handouts on } \\
\text { the physics learning outcomes of grade VIII students of SMP N } 3 \\
\text { Tumijajar even semester is accepted. }\end{array}$} \\
\hline Revised & \\
\hline 2020-09-26 & \\
\hline Keyword: & \\
\hline $\begin{array}{l}\text { Influence, Handout, } \\
\text { Learning Outcomes. }\end{array}$ & \\
\hline
\end{tabular}

\section{Pendahuluan}

Pendidikan mempunyai peranan yang sangat penting dalam kehidupan suatu bangsa. Seiring dengan perkembangan zaman, dunia pendidikan harus melakukan berbagai inovasi agar tidak tertinggal atau mampu menjawab perkembangan ilmu pengetahuan dan teknologi yang sangat cepat.

Proses belajar mengajar merupakan hal yang harus diperhatikan didalam penyelenggaraan pendidikan disuatu instansi pendidikan pada jenjang pendidikan dasar (SD) sampai di perguruan tinggi (PT).

Peraturan Pemerintah Republik Indonesia Nomor 19 tahun 2005, tentang standar Nasional Pendidikan, pada BAB VII (Sarana dan Prasarana) Pasal 42 Butir 1 Setiap satuan pendidikan wajib memiliki sarana yang meliputi perabot, peralatan pendidikan, media pendidikan, buku dan sumber belajar lainnya, bahan habis pakai, serta perlengkapan lain yang yang diperlukan untuk menunjang proses pembelajaran yang teratur dan berkelanjutan.

Sekolah menengah pertama (SMP) merupakan salah satu dari penyelenggara pendidikan yang dilakukan, yang memiliki beberapa tujuan diantaranya, meningkatkan kompetensi dasar siswa di bidang akademis, sesuai dengan tuntutan kurikulum, dan mempersiapkan siswa secara mantap untuk dapat melanjutkan ke jenjang pendidikan berikutnya. Hal ini berarti bahwasannya SMP merupakan pondasi bagi anak setelah lulus dari sekolah dasar (SD), maka konsep-konsep

\footnotetext{
*Corresponding Author:

Nama : Erni Mariana

Lembaga : Universitas Nahdlatul Ulama Lampung

Email : ernimariana@unulampung.ac.id
} 
pengetahuan yang diberikan di SMP harus dapat menjadi dasar pengetahuan setelah mereka melanjutkan ke jenjang berikutnya. Mata Pelajaran fisika adalah cabang mata pelajaran ilmu pengetahuan alam (IPA) yang membahas tentang konsep-konsep alam. Mata pelajaran fisika ini di SMP memuat beberapa hal yakni konsep awal pelajaran fisika dan akan digunakan sampai dengan pendidikan ke jenjang yang lebih tinggi lagi.

Mata Pelajaran fisika adalah cabang mata pelajaran ilmu pengetahuan alam (IPA) yang membahas tentang konsep-konsep alam. Mata pelajaran fisika ini di SMP memuat beberapa hal yakni konsep awal pelajaran fisika dan akan digunakan sampai dengan pendidikan ke jenjang yang lebih tinggi lagi. Berdasarkan hasil prasurvei yang telah dilaksanakan, bahwasanya dalam proses belajar-mengajar pada mata pelajaran fisika di kelas VIII SMP N 3 Tumijajar yang diamati secara langsung tidak menggunakan media handout. Hal ini setelah melakuakan wawancara dengan dua guru bidang studi fisika yang mengajar dikelas VIII, buku cetak (terbitan) merupakan media utama yang dipakai oleh guru. Buku tersebut diberikan hanya pada saat jam pelajaran, sehingga siswa tidak mempunyai pegangan saat diluar jam pelajaran. Karakteristik buku cetak sendiri adalah mempunyai materi yang terlalu banyak dan terlalu detail terhadap konsep-konsep kecil, keaadaan tersebut membuat siswa menjadi malas untuk membaca buku tersebut sehingga siswa kesulitan untuk memahami pokok-pokok materi pembelajaran yang diajarkan. Media pembelajaran mempunyai beberapa kelompok, yaitu (1) media hasil teknologi cetak, (2) teknologi audio-visual, (3) hasil teknologi yang berdasarkan komputer, (4) penggabungan teknologi cetak dan komputer (Arsyad, 2011:29).

Tabel 1. Data Nilai Hasil Belajar Pokok Bahasan Cahaya Dengan Ketuntasan Minimal (KKM) senilai 61 pada Siswa Kelas VIII Semester Genap SMP N 3 Tumijajar.

\begin{tabular}{ccccc}
\hline \multirow{2}{*}{ No } & Nilai & Kategori & $\begin{array}{c}\text { Jumlah } \\
\text { Siswa }\end{array}$ & $\begin{array}{c}\text { Persentase } \\
(\%)\end{array}$ \\
\hline 1 & $\geq 61$ & Tuntas & 16 & $11,1 \%$ \\
2 & $<61$ & Belum & 128 & $88,9 \%$ \\
\multicolumn{7}{c}{ Tumlah } & 144 & $100 \%$ \\
\hline
\end{tabular}

Sumber: Data dokumentasi guru siswa.
Berdasarkan tabel 1, nampak bahwa siswa kelas VIII yang belum mencapai KKM sebanyak 88,9 \% dan siswa yang telah mencapai KKM hanya 11,1\%, jauh dari target yang ditetapkan yakni $70 \%$. Hal ini karena handout berisi pokok-pokok materi yang dapat memudahkan siswa dalam mengikuti pembelajaran sehingga dapat meningkatkan hasil belajar siswa, dan seperti yang diungkapkan bahwa Penyusunan handout dalam kegiatan pembelajaran memiliki beberapa manfaat, diantaranya memudahkan peserta didik saat mengikuti proses pembelajaran, serta melengkapi kekurangan materi, baik materi yang diberikan dalam buku teks maupun materi yang diberikan secara lisan oleh pendidik Prastowo (2011:81).

Pembelajaran yang aktif dan kreatif seperti sekarang ini, peran guru dalam menyampaikan materi akan lebih mudah dengan adanya media sebagai alat bantu pembelajaran. Media pembelajaran ini dapat berupa media yang berbentuk 2 Dimensi maupun 3 Dimensi. Menurut Santyasa (2007) bahwa: Media dua dimensi adalah sebutan umum untuk alat peraga yang hanya memiliki ukuran panjang dan lebar yang berada pada satu bidang datar. Media pembelajaran dua dimensi meliputi grafis, media bentuk papan, dan media cetak yang penampilan isinya tergolong dua dimensi. Sedangkan media tiga dimensi ialah sekelompok media tanpa proyeksi yang penyajiannya. secara visual tiga dimensional. Kelompok media ini dapat berwujud sebagai benda asli baik hidup maupun mati, dan dapat pula berwujud sebagai tiruan yang mewakili aslinya.

Kata "media" berasal dari bahasa latin dan merupakan bentuk jamak dari kata "medium", yang secara harfiah berarati "perantara atau pengantar". Dengan demikian, media merupakan wahana penyalur informasi belajar atau penyalur pesan (Santyasa: 2007).

Media pembelajaran adalah sebagai penyampai pesan (the carries of massages) dari beberapa sumber saluran ke penerima pesan (the receiver of the massages) (Trianto, 2007:75). Dengan adanya media ini, guru akan lebih mudah menyampaikan materi yan akan dipelajari. Tidak hanya berbentuk benda mati saja, bila media diartikan secara luas, maka media bisa berbentuk orang, hal ini seperti yang diungkapkan Gerlach dan Ely dalam Arsyad (2011:3) "Media apabila dipahami secara garis besar adalah manusia, materi, atau 
kejadian yang membangun kondisi yang mampu membuat siswa mampu memperoleh pengetaahuan, ketrampilan dan sikap". Kemudian diperjelas lagi oleh Santyasa (2007) bahwa Proses pembelajaran mengandung lima komponen komunikasi, yakni guru (komunikator), bahan pembelajaran, media pembelajaran, siswa (komunikan), dan tujuan pembelajaran. Jadi, media pembelajaran adalah segala sesuatu yang dapat digunakan untuk menyalurkan pesan (bahan pembelajaran), sehingga dapat merangsang perhatian, minat, pikiran, dan perasaan siswa dalam kegiatan belajar untuk mencapai tujuan belajar.

Media sebagai alat bantu dalam proses pembelajaran adalah suatu kenyataan yang tidak dapat dipungkiri. Karena memang gurulah yang menghendakinya untuk membantu tugas guru dalam menyampaikan pesan-pesan dari bahan ajar yang diberikan oleh guru kepada anak didik. Media pembelajaran diharapkan dapat memeberikan manfaat, antara lain: (1) Bahan yang disajikan lebih jelas maknanya bagi siswa, dan tidak bersifat verbalistik: (2) Metode pembelajaran lebih bervariasi: (3) Siswa menjadi lebih aktif melakukan beragam aktivitas:

Pembelajaran lebih menarik: (5) Mengatasi keterbatasan ruang.

Sehingga, perlu adanya kajian terkait pembelajaran fisika akan terlaksana lebih baik jika didukung dengan penggunaan handout, sehingga dapat dengan mudah mencapai tujuan pembelajaran yang diharapkan. Tujuan pembelajaran yang dimaksud tidak hanya mencakup kemampuan pengetahuan, namun juga mencakup kemampuan sikap dan keterampilan. Dengan demikian, diharapkan prestasi belajar fisika semakin meningkat.

\section{Metode Penelitian}

Rancangan Penelitian

Rancangan Penelitian yang peneliti gunakan adalah Postest-Only Control Design. Dimana desain ini menggunakan dua kelompok yang akan diteliti. Kelompok pertama mendapatkan perlakuan (treatment) atau disebut sebagai kelas eksperimen yaitu kelas yang menggunakan handout dalam pembelajaran, sedangkan kelompok yang kedua sebagai kelompok pengendali (control) atau disebut sebagai kelas kontrol yaitu kelas yang mendapatkan pembelajaran seperti biasa yakni tanpa menggunakan handout. Dalam penelitian ini pengaruh treatment dapat dianalisis dengan menggunakan uji beda, memakai statistik t-test. Jika terdapat perbedaan yang signifikan antara kelompok kontrol dan kelompok eksperimen, maka perlakuan yang diberikan berpengaruh secara signifikan Sugiono (2010:76).

Jenis Penelitian

Penelitian ini menggunakan pendekatan kuantitatif yaitu eksperimental dengan menggunakan kelas kontrol dan kelas eksperimen dalam penelitian ini.

\section{Waktu dan Tempat Penelitian}

Waktu Penelitian dilaksanakan pada Januari sampai Maret 2019/2020. Tempat Penelitian yaitu SMP Negeri 3 Tumijajar terdiri dari 11 kelas. Jadwal belajar dimulai dari jam 07.30 sampai dengan 12.30 WIB.

Target/Subjek Penelitian

Populasi yang digunakan dalam penelitian ini adalah seluruh siswa kelas VIII SMP N 3 Tumijajar yang terdiri dari 4 kelas yakni kelas VIIIA, kelas VIIIB, kelas VIIIC, dan kelas VIIID dengan setiap kelas VIII berjumlah 34 siswa. Subjek pada penelitian ini adalah kelas VII B dan VII D dengan jumlah siswa 41 tiap kelas.

\section{Prosedur}

Pengambilan sampel dalam penelitian ini diambil secara teknik cluster random sampling yaitu dengan pengundian secara acak tanpa ada yang diistimewakan. Adapun yang undi secara acak adalah kelasnya bukan siswanya. Pengambilan sampel ini dilakukan dengan cara menuliskan nama-nama kelas pada setiap selembar kertas dan digulung kemudian diundi, sehingga diperoleh dua kelas untuk diambil sebagai sampel. Kemudian kedua kelas ini diundi lagi untuk menentukan kelas mana yang akan dijadikan sebagai kelas kontrol dan kelas eksperimen. Dari empat kelas VIII, terambil dua kelas sebagai sampel penelitian yakni kelas VIIIB sebagi kelas kontrol dan Kelas VIIID sebagai kelas eksperimen.

\section{Teknik Analisis Data}

Analisis yang digunakan adalah metode statistik $T$ tes yaitu terdiri dari $\mathrm{Uji}$ normalitas, uji homogenitas, uji hipotesis. Instrumen pengumpulan data dalam 
pengumpulan data, peneliti menggunakan dua instrumen, yakni instrumen berbentuk lembar observasi dan lembar tes. Suatu intrumen penelitian sebelum digunakan untuk mengambil data penelitian, dilakukan pengujian kemantapan alat pengumpul data. Pada penelitian ini instrumen yang dipakai adalah tes tertulis yang digunakan adalah tes subjektif yang berbentuk uraian. Dalam menguji kemantapan tes sebagai instrumen pengumpul data maka dilakukan berbagai pengujian Validitas dan Reliabilitas.

\section{Hasil Penelitian dan Pembahasan}

a. Pembelajaran dikelas eksperimen

Proses pembelajaran pada kelas eksperimen yakni pemberian materi tentang cahaya yang meliputi pemantulan, pembiasan, cermin dan lensa. Kegiatan pembelajaran dilaksanakan selama tiga pertemuan atau selama 3x90'. Setiap siswa pada kelas eksperimen diberikan handout yang digunakan sebagi media pembelajaran.

Pertemuan pertama, pembelajaran dilaksanakan dengan menggunakan metode praktikum dan diskusi kelompok pada subpokok materi pemantulan dan cermin datar dengan menggunakan media handout. Kegiatan pembelajaran diawali dengan memberikan motivasi kepada siswa dan mengajak siswa menggali pengalamannya yang berkaitan dengan materi pembelajaran, seperti mananyakan ketika mereka bercermin dirumah. Kemudian siswa dibimbing guru untuk membentuk kelompok setiap kelompok terdiri dari 5-7 orang. Kemudian guru menjelaskan materi secara ringkas, setelah itu siswa melakukan praktikum sederhana yakni tentang hukum pemantulan cahaya, dengan cara menyorotkan sinar laser mainan kecermin datar yang sudah disusun sedemikina rupa sehingga jalan sinar laser mainan tersebut dapat dilihat. Setelah melakukan praktikum siswa mendiskusikan hasil praktikum dengan menjawab pertanyaan-pertanyaan yang telah diberikan pada lembar kegiatan praktikum, diantaranya:

1. Apakah sinar datang, sinar pantul, dan garis normal terletak pada satu bidang datar?

2. Apakah besarnya sudut datang dan sudut pantul sama besar?

Siswa mendiskusikannya dengan bantuan media handout dan kemudian perwakilan kelompok menyampaikan hasilnya didepan kelas. Setelah semua kelompok menyampaikan hasil diskusinya, kemudian guru meluruskan permasalahan yang ada, sebagai contoh sebagian siswa masih ada yang bingung penggambaran sinar datang, sinar pantul, sudut datang dan sudut pantul. Dengan pembelajaran seperti ini siswa lebih aktif, karena semua siswa telibat disemua kegiatan pembelajaran dan siswa menjadi mudah untuk memahami materi karena dengan bantuan handout yang mudah digunakan. Guru memberikan penghargaan kepada kelompok yang mempunyai kinerja yang paling baik. Kegiatan diakhiri dengan menyimpulkan secara bersama-sama materi pembelajaran, kemudian guru memberikan tugas rumah dan setelah itu kegiatan pembelajaran ditutup dengan salam.

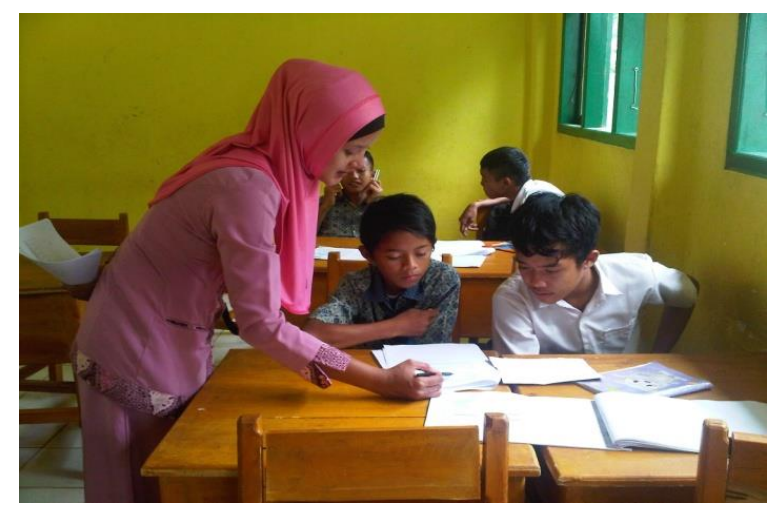

Gambar 1. Siswa sedang mendiskusikan hasil praktikum.

Pertemuan kedua, sub pokok materi pembelajaran adalah cermin cekung dan cermin cembung. Kegiatan diawali dengan guru mengucapkan salam kepada siswa dan semua siswa menjawab salam. Kegiatan ini bertujuan untuk mengkondisikan siswa keadaan dalam siap belajar, kemudian setiap siswa diberikan handout yang telah disiapkan. Setah itu guru menanyakan tentang kejadian dikehidupan sehari-hari yang berkaitan dengan materi pembelajaran, yakni pernahkah kalian bercermin disebuah sendok, apa yang terjadi. Sebagian siswa menjawab sudah tapi dari mereka belum mengerti kenapa terjadi demikian yaitu ketika dicekungan sendok bayangan terbalik, dan pada saat di bagian belakang sendok bayangan membesar. Kemudian siswa dibimbing guru untuk membentuk kelompok setiap kelompok terdiri dari 5-7 orang. Kemudian guru menjelaskan materi secara ringkas dengan bantuan handout, 
setelah itu guru memberikan pertanyaan diskusi kepada setiap kelompok, diantaranya:

1. Bagaimanakah pembetukan bayangan yang terjadi ketika benda diletakkan diantara titik fokus $(F)$ dan pusat kelengkungan cermin $(M)$ didepan cermin cekung?

2. Contoh lain dari penggunaan cermmin cekung dan cembung dalam kehidupan sehari-hari.

Siswa dengan menggunakan handout mendiskusikan pertanyaan yang diberikan guru, setelah itu perwakilan kelompok menyampaikan hasilnya didepan kelas. Setelah semua kelompok selesai menyampikan, kemudian guru megklarifikasi jawaban siswa. Kemudian guru memberikan penghargaan kepada kelompok yang mempunyai kinerja yang paling baik. Setelah itu guru memberikan tugas rumah kepada siswa, siswa mencatat tugas yang diberika. Kemudian kegiaatan pembelajaran diaakhiri dengan salam. Ada sebagian siswa yang bertanya handout yang diberikan boleh dibawa pulang atau dikumpul lagi, handout diberikan agar siswa mempunyai pegangan saat diluar jam pembelajran disekolah jadi handout tersebut adalah milik siswa.

Pertemuan ketiga, pada pertemuan ketiga materi pembelajaran adalah tentang pembiasan dan lensa, kegiatan dibuka dengan salam oleh guru. Kemudian guru menyakan kaitan materi dengan kehidupan sehari-hari yakni pernahkah kalian mencelupkan kayu yang lurus kedalam air. semua siswa menjawab sudah dan kayu terlihat bengkok. Kemudian guru menjelaskan bahwa hal tersebut berkaitan dengan pembelajaran. Kegiatan dilanjutkan berdiskusi kelompok, setelah pembelajaran selesai kemudian guru menjelaskan pertanyaan awal tentang kayu yang bengkok ketika diair, dan siswa menjadi tau kenapa kayu bisa terliat bengkok, adalah karena pembiasan.

Penelitian ini juga melibatkan observer yang bertugas untuk mengobservasi keterlaksaan rencana pembelajaran dan penggunaan handout saat pembelajaran berlangsung. Pemberian tes dilakuakan saat materi pembelajaran sudah selesai, kemudian menyebarkan angket respon siswa untuk melihat bagaimana tanggapan siswa tentang pembelajaran yang menggunakan media handout.

\section{b. Pembelajaran dikelas kontrol}

$$
\text { Proses yang dilakukan yakni }
$$

memberikan pembelajaran tentang materi cahaya pada kelas kontrol dengan bantuan buku cetak yang biasa digunakan. Proses pembelajaran dikelas kontrol hampir sama dengan kelas eksperimen yang membedakan hanya media pembelajaran yang digunakan. Pembelajaran juga dilakukan dalam tiga kali pertemuan atau $3 \times 90$ '. Materi pembelajaran adalah cahaya yang meliputi pemantulan, pembiasan, cermin dan lensa. Pada pertemuan pertama subpokok materi yang diajarkan adalah pemantulan dan cermin datar, pada pertemuaan kedua adalah cermin cekung dan cermin cembung, dan pada pertemuan ketiga adalah pembiasan dan lensa. Adapun langkahlangkahnya adalah sebagi berikut: Guru membimbing siswa untuk melakukan pembentukan kelompok yang berjumlah 5-7 orang dalam setiap kelompok, setelah itu guru menjelaskan secara singkat materi yang akan dipelajari. Kemudian guru memberikan pertanyaan-pertanyaan diskusi kepada setiap kelompok, dan siswa mendiskusikan pertanyaan-pertanyaan itu dengan kelompoknya masing-masing. Setelah itu setiap kelompok menyampaikan hasil diskusinya didepan kelompok yang lain. Pada kelas kontrol juga diberikan tes yang digunakan sebagi evaluasi pembelajran yang telah berlangsung, setelah pembelajaran pembelajran materi cahaya sudah selesai. Pada kelas kontrol juga dilakuakan observasi tetapi hanya untuk keterlaksanaan rencana pembelajaran.

Berdasarkan penelitian yang telah dilakukan diperoleh data kuantitatif dan data kualitatif. Data kuantitatif meliputi data hasil belajar siswa setelah melakukan tes akhir (posttest) sedangkan data kuantitatif meliputi lembar observasi dan angket.

1. Data Kuantitatif

Berdasarkan penelitian yang telah dilakukan diperoleh data kuantitatif yang meliputi data hasil belajar siswa, yang dilakukan setelah materi cahaya pada kedua kelas selesai diajarkan, dengan memberikan tes akhir (posttest) dalam bentuk 10 soal esai. Perhitungan data yang dimaksudkan meliputi nilai rata-rata hasil belajar dan jumlah siswa terdapat pada lampiran 20. Adapun data nilai hasil belajar (posttest) siswa kelas eksperimen dan kelas kontrol sebagai berikut: 
Tabel 2. Nilai posttest Pada Kelas Eksperimen dan Kelas Kontrol.

\begin{tabular}{cccc}
\hline \multicolumn{2}{c}{ Kelas Eksperimen } & \multicolumn{2}{c}{ Kelas Kontrol } \\
\hline $\mathrm{N}=33$ & Posttest & $\mathrm{N}=33$ & Posttest \\
$\bar{X}$ & 71,24 & $\bar{X}$ & 62,93 \\
\hline
\end{tabular}

Berdasarkan tabel 2, dapat diuraikan bahwa peningkatan hasil belajar siswa sebagai berikut:

a. Secara keseluruhan hasil belajar siswa dilihat dari hasil posttets mempunyai ratarata 71,24 dan 62,93. Hal ini menunjukkan bahwa hasil belajar siswa secara keseluruhan berbeda dan termasuk dalam kategori baik.

b. Perbandingan rata-rata hasil belajar siswa berdasarkan (kelas eksperimen dan kelas kontrol) adalah 71,24>62,93. Hal ini menunjukkan bahwa hasil belajar siswa pada kelas eksperimen lebih baik dari pada siswa kelas kontrol.

Berdasarkan penelitian yang telah dilakukan diperoleh data kuantitatif yang meliputi data hasil belajar siswa, yang dilakukan setelah materi cahaya pada kedua kelas selesai diajarkan, dengan memberikan tes akhir (posttest) dalam bentuk 10 soal esai.

Gambaran perbandingan posttest antara kelas eksperimen dan kelas kontrol dilihat pada gambar 1 .

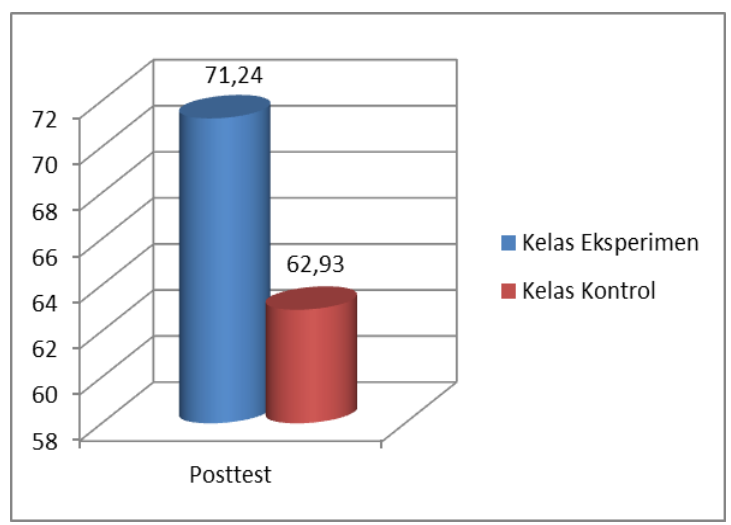

Gambar 2. Grafik Perbandingan Hasil Posttest Kelas Eksperimen dan Kelas Kontrol

\section{Data kualitatif}

a. Observasi

Data observasi ini menjelaskan penggunaan handout saat proses pembelajaran berlangsung. Dari hasil observasi yang telah dilakukan oleh 3 observer didapat data kualitatif.

\section{b. Angket}

Data angket ini menjelaskan mengenai respon siswa terhadap pelaksanaan pembelajaran IPA Fisika pada pokok bahasan cahaya dengan menggunakan media handout. Instrumen ini terdiri dari tujuh item pernyataan dan diberikan kepada 33 siswa kelas ekperimen setelah pembelajaran selesai diajarkan.

Analisis data meliputi uji normalitas (uji kecocokan chi kuadrat) dan uji homogenitas (uji F). Setelah didapat hasil uji normalitas dan uji homogenitas baru selanjutnya dilakukan uji perbedaan dua ratarata menggunakan uji-t untuk menguji hipotesis. Uji normalitas bertujuan untuk mengetahui apakah sampel yang dijadikan penelitian berasal dari populasi yang berdistribusi normal atau tidak. Uji homogenitas bertujuan untuk melihat apakah varians antara kedua sampel homogen atau tidak. Uji hipotesis bertujuan untuk mengetahui apakah ada atau tidak perbedaan hasil belajar siswa.

Berdasarkan hasil analisis data pada kelompok eksperimen dan kelompok kontrol ini keduanya berada pada distribusi normal, hal tersebut terbukti pada hasil uji prasyarat analisis yang menyatakan bahwa $\chi_{\text {hitung }}^{2}$ $\chi_{\text {tabel }}^{2}$ dimana $\chi_{\text {tabel }}^{2}$ pada taraf signifikansi 5\% sebesar 7.81 dan pada taraf signifikansi $1 \%$ sebesar 11,13 sedangkan $\chi^{2}$ hitung kelas eksperimen sebesar 4,95 dan $\chi^{2}$ hitung kelas kontrol sebesar 2,12. Selain itu kedua kelompok ini juga bersifat homogen, terbukti berdasarkan uji prasyarat analisis yang menyatakan bahwa $F_{\text {hitung }}<\mathrm{F}_{\text {tabel }}$ dimana $\mathrm{F}_{\text {tabel }}$ pada taraf signifikansi $10 \%$ sebesar 1,82 dan pada taraf signifikansi $2 \%$ sebesar 2,34 sedangkan $\mathrm{F}_{\text {hitung }}$ sebesar 1,26.

Pengujian hipotesis dilakukan dengan menggunakan uji-t, pada taraf kepercayaan 95\%. Hasil uji kesamaan dua rata-rata dilakukan untuk mengetahui apakah ada perbedaan rata-rata hasil belajar siswa kelas eksperimen dengan hasil belajar kelas kontrol, diperoleh nilai $t_{\text {hitung }}=3,49$ dan nilai $t_{\text {tabel }}=$ 2,00. Hasil pengujian yang diperoleh menunjukkan bahwa $t_{\text {hitung }}>t_{\text {tabel }}$ atau 3,49> 
2,00, sedangkan pada taraf kepercayaan $99 \%$ diperoleh $t_{\text {tabel }}=2,66$ yang berarti $t_{\text {hitung }}>t_{\text {tabel }}$ atau 3,49>2,66 dengan demikian $\mathrm{H}_{0}$ ditolak dan $\mathrm{H}_{1}$ diterima. Perbandingan rata-rata hasil belajar siswa berdasarkan (kelas eksperimen dan kelas kontrol) adalah 71,24 > 62,93. Hal ini menunjukkan bahwa hasil belajar siswa pada kelas eksperimen lebih baik dari pada siswa kelas kontrol serta pembelajaran menggunakan media handout pada konsep cahaya pada taraf kepercayaan $95 \%(\alpha=0,05)$ dan taraf kepercayaan $99 \% \quad(\alpha=0,99)$ berpengaruh terhadap hasil belajar fisika.

Berdasarkan data yang telah dipaparkan pada halaman sebelumnya dapat dijelaskan bahwa, penggunaan handout sangat bermanfaat bagi guru hal ini senada dengan Fitria dalam Wibowo (2011) yang menyatakan bahwa dengan penggunaan handout sangat membantu pada saat proses pembelajaran. Selain itu juga bermanfaat bagi siswa karena dengan adanya handout siswa tidak repotrepot meresum keterangan dari guru atau dari buku cetak karena di dalam handout sudah terdapat materi yang singkat dan jelas yang dapat difahami oleh siswa hal ini juga di jelaskan Steffen dan Peter Ballstaedt dalam Prastowo (2011:80) salah satu fungsi handout adalah membantu peserta didi agar tidak perlu mencatat. Dengan demikian adanya handout ini dapat memudahkan guru dalam menyampaikan materi dan juga siswa dalam mempelajari materi yang diajarkan.

\begin{tabular}{|c|c|c|}
\hline \multirow{2}{*}{ No } & \multicolumn{2}{|c|}{ Kelebihan } \\
\hline & Handout & Bahan ajar lainnya \\
\hline 1 & $\begin{array}{l}\text { Siswa dapat } \\
\text { belajar sesuai } \\
\text { dengan } \\
\text { kecepatan } \\
\text { masing - masing }\end{array}$ & $\begin{array}{l}\text { Sulit memberikan } \\
\text { bimbingan kepada } \\
\text { pembacanya yang } \\
\text { mengalami kesulitan } \\
\text { memahami bagian- } \\
\text { bagian tertentu }\end{array}$ \\
\hline 2 & $\begin{array}{l}\text { Disamping dapat } \\
\text { mengulang } \\
\text { materi, siswa } \\
\text { dapat mengikuti } \\
\text { urutan pikiran } \\
\text { secara logis }\end{array}$ & $\begin{array}{lr}\text { Sulit } & \text { memberikan } \\
\text { umpan balik } & \text { untuk } \\
\text { pertanyaan } & \text { yang } \\
\text { diajukan } & \text { yang } \\
\text { memiliki } & \text { banyak } \\
\text { kemungkinan } & \\
\text { jawaban } & \text { atau } \\
\text { pertanyaan } & \text { yang } \\
\text { membutuhkan } & \\
\text { jawaban } & \text { yang } \\
\text { kompleks } & \text { dan } \\
\text { mendalam; } & \\
\end{array}$ \\
\hline
\end{tabular}

\begin{tabular}{lllr}
\hline 3 & \multicolumn{1}{l}{ Perpaduan teks } & Tidak & mampu \\
dan gambar & mempresentasikan \\
dapat menambah & gerakan, pemaparan \\
daya tarik serta & materi bersifat linear, \\
memperlancar & tidak mampu \\
pemahaman & mempresentasikan \\
& informasi yang & kejadian secara \\
& disampaikan & berurutan; \\
\hline 4 & Lebih ekonomis & untuk membuat \\
& dan mudah & bahan ajar cetak yang \\
& terdistribusi & bagus, diperlukan \\
& & biaya yang tidak \\
& sedikit
\end{tabular}

Sumber: (Arsyad, 2000: 38)

Hal ini membuat hasil belajar dikelas eksperimen lebih baik dari pada dikelas kontrol, dengan adanya handout siswa termotivasi untuk membaca handout yang memiliki materi yang sangat ringkas dan jelas dibandingkan dengan buku cetak yang menyajikan materi terlalu banyak selain itu siswa memiliki pegangan saat diluar jam pembelajaran sehingga siswa bisa belajar dimana saja. Sebagai contoh ketika siswa belajar dirumah, siswa memiliki rujukan yang mudah dimengerti, singkat dan padat maka siswa akan lebih mudah untuk memahami suatu konsep fisika dan tentunya akan mempengaruhi hasil belajarnya.

Pembelajaran menggunakan handout siswa termotivasi dan senang melakukan kegiatan belajar yang menarik dan bermakna bagi dirinya. Hal ini terlihat dari data angket respon siswa, yang menunjukkan ada 24 siswa menjadi lebih lebih giat belajar fisika. Dan dari jawaban siswa ketika diberi pertanyaan apakah tertarik dengan pembelajaran seperti itu, hampir seluruh siswa menjawab "ya", mereka memberi pernyataan bahwa tertarik dengan handout yang diberikan oleh guru kepada mereka dan karena handout memudahkan mereka dalam mempelajari materi. Hal ini menunjukkan sebagian besar siswa memiliki respon belajar yang baik saat pembelajaran, dan ini dikarenakan siswa dengan mudah mempelajari materi dengan bantuan handout.

Berdasarkan uraian menunjukkan bahwa pengunaan handout menyebabkan terjadinya hasil akhir yang berbeda antara kelas eksperimen dengan kelas kontrol. Nilai rata-rata hasil tes kelas eksperimen lebih besar dari pada nilai rata-rata kelas kontrol. Dengan demikian diketahui bahwa penggunaan handout dalam pembelajaran dapat 
berpengaruh terhadap hasil belajar. Hasil penelitian ini memperkuat hasil penelitian terdahulu yang dilakukan oleh Wibowo (2011) yang juga menarik kesimpulan bahwa terdapat pengaruh penggunaan handout terhadap hasil belajar. Hasil belajar kognitif adalah perubahan perilaku yang terjadi dalam kawasan kognisi (Purwanto, 2010:50). Proses belajar yang melibatkan kognisi meliputi kegiatan sejak dari penerimaan stimulus eksternal oleh sensori, penyimpanan dan pengolahan dalam otak menjadi informasi hingga pemanggilan kembali informasi ketika diperlukan untuk menyelesaikan masalah. Hasil belajar kognitif tidak merupakan kemampuan tunggal. Kemampuan menimbulkan perubahan perilaku dalam domain kognitif meliputi beberapa tingkat atau jenjang. Banyak klasifikasi dibuat para ahli psikologi dan pendidikan, namun klasifikasi yang paling banyak digunakan adalah yang dibuat oleh Benjamin S Bloom. Menurut Bloom (dalam Purwanto, 2010:50) bahwa secara hirarki tingkat hasil belajar kognitif mulai dari yang paling rendah dan sederhana yaitu hafalan sampai yang paling tinggi dan komplek yaitu evaluasi. Makin tinggi tingkat maka makin kompleks dan penguasaan suatu tingkat mempersyaratkan penguasaan tingkat sebelumnya. Enam tingkat itu adalah hafalan (C1), ingatan (C2), penerapan (C3), analisis (C4), sintesis (C5), dan evaluasi (C6).

\section{Simpulan dan saran Simpulan}

Berdasarkan analisis data dan pengujian hipotesis dalam penelitian ini, diketahui bahwa rata-rata nilai hasil belajar kelas eksperimen $(71,24)$ lebih besar daripada kelas kontrol $(62,92)$, maka dapat disimpulkan penggunaan handout berpengaruh terhadap hasil belajar fisika siswa kelas VIII SMP Negeri 3 Tumijajar semester genap.

\section{Saran}

Sebagai tindak lanjut dari hasil penelitian ini maka peneliti dapat memberikan beberapa saran sebagai berikut:

\section{Saran untuk Guru}

Guru harus memahami karakteristik pendekatan pembelajaran yang digunakan sebelum menerapkannya pada pembelajaran di kelas. Guru hendaknya mulai untuk menggunakan handout untuk pembelajaran fisika di kelas agar sesuai dengan karakteristik siswa di kelas dan siswa dapat menerima dengan baik konsep-konsep fisika yang dipelajarinya, tidak hanya mengandalkan LKS yang tidak sesuai dengan siswa dan terdapat kesalahan dalam penyampaian konsep-konsep fisika.

\section{Saran untuk Peneliti}

Hasil penelitian ini dapat digunakan sebagai acuan untuk mnegmbangkan penelitian sejenis, terutama penelitian penggunaan handout dalam pembelajaran fisika. Peneliti dapat mengembangkan handout dengan karakteristik pendekatan pembelajaran dan materi yang berbeda. Peneliti harus memahami tentang karakteristik pendekatan pembelajaran yang digunakan dan siswa yang dijadikan sampel hendaknya diberikan pemahaman yang jelas tentang pembelajaran dengan menggunakan handout.

\section{Daftar pustaka}

Abdurrahman, M. 2003. Pendidikan Bagi Anak Berkesulitan Belajar. Jakarta: PT. Reneka Cipta

Arikunto, Suharsimi. 2006. Prosedur Penelitian Suatu Pendekatan Praktik. Jakarta: PT. Rineka Cipta

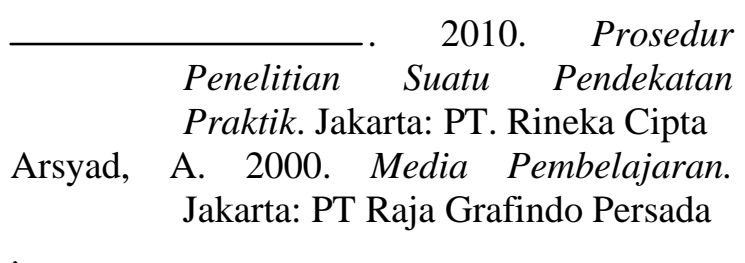

Arsyad, A. 2011. Media Pembelajaran. Jakarta: Rajawali Press

Badan Pengembangan Akademik Universitas Islam Indonesia. 2009. Panduan Pembuatan Bahan Ajar (DIKTAT, MODUL, HANDOUT), (Online), (http://www.uii.ac.id, diakses pada tanggal 5 november 2012)

Dimyati dan Mujiono. 2006. Belajar dan Pembejaran. Jakarta: PT. Rineka. Cipta

Kamriantiramli. 2011. Revisi Taksonomi Bloom Ranah Kognitif, (Online), (http://kamriantiramli.wordpress.co $\mathrm{m}$, diakses tanggal 04 Januari 2013) 
KEMENDIKBUD. 2012. Peraturan Pemerintah Republik Indonesia No. 19 Tahun 2005 Tentang Standar Nasional Pendidikan, (Online), (http://www.paudni.kemdikbud.go.i d, diakses pada 04 Januari 2013)

Kountur, Ronny. 2007. Metode Penelitian untuk Penulisan Skripsi dan Tesis. Jakarta: Buana Printing

Kriyantono, Rachmat. 2009. Teknik Praktis Riset Komunikasi. Jakarta: Kencana.

Prastowo, Andi. 2011. Panduan Kreatif Membuat Bahan Ajar Inovatif. Yogyakarta: DIVA press

Purwanto. 2010. Evaluasi Hasil Belajar. Yogyakarta: Pustaka Pelajar

Sanaky, Hujair AH. 2011. Media Pembelajaran, Buku Pegangan Wajib Guru dan Dosen. Yogyakarta:Kuakaba Dipantara

Sanjaya, Wina. 2008. Perencanaan Dan Desain Sistem Pembelajaran. Jakarta: PT. Rineka cipta

Santyasa, I Wayan. 2007. Landasan Konseptual Media Pembelajaran, (Online), (http://file.upi.edu, diakses pada tanggal 5 november 2012)

Sugiyono. 2010. Metode Penelitian Tindakan Kelas Pendekatan Kuantitatif, Kualitatif, dan $R \& D$. Bandung: Alfabeta

Supartin. 2005. Studi Deskriptif Hasil Belajar Fisika, (online). (http://journal.ung.ac.id, diakses pada tanggal 5 november 2012)

Sutjiono, Thomas W. A . 2005. Pendayagunaan Media Pembelajaran, (online), (http://www.penabur.org, diakses pada tanggal 2 november 2012)
Trianto. 2007. Model Pembeajaran Terpadu dalam Teori dan Praktek. Jakarta: Prestasi Pustaka. 